\title{
«Зцілення на відстані»: виклики, які вирішує телекардіологія
}

\section{Д.К. Чернікова}

лікар, професійний член Європейського товариства кардіологів (ESC), амбасадор в Україні від Робочої групи з телекардіології Міжнародного товариства з телемедицини та e-Health (ISfTeH)

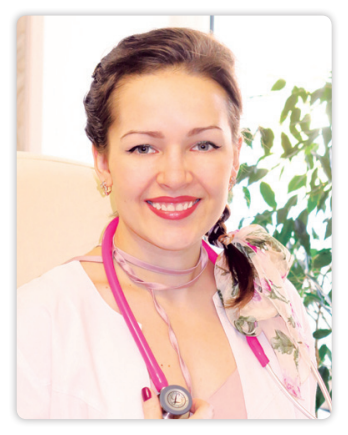

«Підключення людей до телемедицини» стало гаслом та символом 2020 р. у сфері e-Health та телеінновацій. Тому цілком логічно, що значна увага світової медичної спільноти у лютому 2021 р. була прикута до 25-ї Міжнародної конференції Міжнародного товариства з телемедицини та e-Health (International Society for Telemedicine \& e-Health ISfTeH) в Японії та 24-ї Щорічної академічної конференції Японської асоціації з телемедицини (Japanese Telemedicine and Telecare Association - JTTA). Один з найбільших заходів e-Health у світі зібрав спікерів - спеціалістів у галузі телемедицини 320 країн. Цьогоріч у зв'язку з поточною пандемічною ситуацією конференція вперше пройшла в онлайн-форматі. Прогресивне людство невпинно шукає та створює передумови розвитку в майбутньому. Так, лютий 2021 р. відзначився мегамісією Національного управління з аеронавтики і дослідження космічного простору (National Aeronautics and Space Administration — NASA) з пошуку доказів існування життя на Марсі. Можливість зробити це - справжній прорив всесвітнього значення. Але пошук передумов йде не лише у космосі: лікарі в усьому світі теж у пошуку - удосконалення системи надання медичної допомоги. Поштовх до цього - критична ситуація, спровокована COVID-19. У 2020 р. справжній прорив здійснений цифровими технологіями в кардіології.

\section{Цифрова трансформація охорони здоров'я}

Місцем ефіру для міжнародної конференції вибрано місто Такасакі. Одним із ключових пунктів програми стали міжнародні симпозіуми. Спікери з Китаю, Данії, Італії, США, Канади, Франції, Швеції, Філіппін, Фінляндії, України висвітлювали теми цифрової трансформації в епоху COVID-19.

Доповіді фахівців стосувалися дистанційної медичної освіти, змін регламенту надання віртуальної медичної допомоги, зокрема пацієнтам із психічними розладами. Окремо висвітлений досвід фахівців США щодо застосування телемедицини для підтримки відмови від тютюнопаління. Увага учасників була прикута також до можливостей впровадження штучного інтелекту, наприклад у сфері поліпшення якості життя людей з обмеженими фізичними можливостями. Тема телемоніторингу розглянута з боку ефективного попереднього виявлення гострих форм захворювання. Підвищений інтерес викликало питання впровадження 5G-технологій для подальшого вдосконалення світової телемедицини.

\section{Провідник у світ кардіоінновацій}

Міжнародний симпозіум з телекардіології у рамках конференції ISfTeH організований головою Робочої групи з телекардіології, керівником Interventional Cardiology Department Centre Hospitalier Montlucon (Франція) доктором Alexandru Mischie та віцепрезидентом Товариства кардіологів Румунії професором Dan Gaita.

Представники Робочої групи з телекардіології - професор Stefano Omboni (Італія), лікар Дарина Чернікова (Україна) та доктор Mihai Trofenciuc (Румунія) — підготували доповіді про оновлення стосовно лікування пацієнтів із артеріальною гіпертензі-

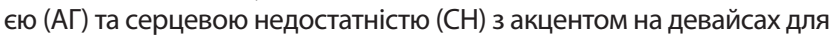
віддаленого моніторингу, а також щодо нововведень у наданні кардіологічної допомоги в умовах COVID-19.

Наразі Робоча група з телекардіології у складі ISfTeH $€$ найбільшим світовим співтовариством, що об'єднує фахівців у галузі кардіології та телемедицини $3>20$ країн.

\section{Досвід вартий уваги}

Досвідом ведення пацієнтів із АГ за допомогою технологій дистанційного моніторингу поділився 3 колегами справжній професіонал своєї справи, директор Італійського інституту телемедицини, професор Stefano Omboni (Варезе, Італія).

Пацієнти з високим артеріальним тиском (АТ), ожирінням, цукровим діабетом та перенесеним інсультом мають найбільші переваги від використання телемедицини, бо саме телемоніторинг АТ на сьогодні $\epsilon$ основним застосуванням телемедицини в галузі лікування АГ.

Приблизно у 1,13 млрд людей в усьому світі діагностовано АГ [1]. Згідно з аналізом результатів скринінгу АТ, опублікованим у «The Lancet Global Health», 34,9\% загальної кількості учасників дослідження (1,12 млн) мали АГ, тоді як 17,3\% не отримували лікування, а у $46,3 \%$ учасників дослідження АТ було неконтрольованим, незважаючи на лікування [2]. За прогнозами поширеність цієї хвороби підвищиться до 1,26 млрд до 2025 р. [1]. Додатково турбує, що рівень АГ зростає серед людей молодого віку та у розвинених країнах. Встановлено, що сучасна проблема високої поширеності АГ пов'язана з недостатнім контролем АТ в усьому світі.

«Для поліпшення виявлення та контролю АТ ми повинні розгдядати out-of-office (домашнє та амбулаторне) вимірювання АТ як обов'язкове при АГ. Також нам потрібно використовувати e-Health-рішення, щоб налагодити більш ефективний та оперативний зв'язок між медичним працівником та пацієнтом», - зазначив професор S. Omboni.

Існують різні типи моніторингових пристроїв, такі як upper-arm електронні автоматизовані пристрої, пристрої для контролю кількох параметрів (медичні трикодери), програми для смартфонів, смартфони, що виконують функцію cuffless моніторів АТ та wearables. Cьогодні набувають популярності пристрої cuffless (без манжет), засновані на тонометрії зап'ястя або фотоплетизмографії пальців.

щодо мобільних додатків для самоконтролю, то для пацієнтів наразі доступні такі додатки для вимірювання AT: Blood Pressure Monitor App, Blood Pressure Companion App, Blood Pressure Tracker and Qardio App.

Нещодавно оновлений метааналіз, що включав 46 рандомізованих контрольованих досліджень, підтвердив перевагу домашнього телемоніторингу АТ перед звичним методом вимірювання АТ пацієнтом [3]. Технології спрощують передачу даних лікарю. Це робиться оперативно та за розкладом, який потрібний для ефективного спостереження. Для лікаря це - можливість оцінювати стан пацієнта в режимі реального часу, а не за фактом його звернення за допомогою.

Телемедицина має специфічні рекомендації для лікування паці$\epsilon$ нтів із АГ лише у дійсних протоколах АСС/АНА 2017 р., де телемоніторинг out-of-office AT має найвищий клас рекомендацій та рівень доказовості (IA). Рекомендації ESH/ESC 2018 р. визначають телемоніторинг або використання смартфону як доповнення до моніторингу АТ для покращення прихильності до лікування, однак ці рекомендації є загальними.

Наразі лікарям доступні рекомендації «Most Recent Comprehensive International Evidence and Recommendations on the Use of 
Telemedicine for the Management of Arterial Hypertension: An International Expert Position Paper» [4] як одне з основних джерел найактуальнішої інформації щодо використання телемедицини для ведення пацієнтів із АГ.

\section{Телекардіологія та COVID-19}

Зв'язок між цими двома актуальними темами презентований у доповіді Д. Чернікової.

«Ми живемо в динамічному світі технологій, який потребує від нас прийняття швидкомінливих умов. Найбільш яскраво ми відчули це під час пандемії, оскільки боротьба з COVID-19 вимагає адаптацій та проривних нововведень у галузі охорони здоров'я, особливо коли мова йде про лікування когорт пацієнтів високого та дуже високого серцево-судинного ризику. Телемедицина повинна стати способом зміни парадигми кардіологічної допомоги під час COVID-19», — зазначила лікар.

У доповіді представлені результати досліджень у галузі використання телекомунікаційних та цифрових технологій для успішного надання невідкладної кардіологічної допомоги під час пандемії, приклади ефективної роботи відділень інтенсивної терапії (teleICU) з використанням телемедицини та нові мобільні додатки для взаємодії між лікарями та пацієнтами з COVID-19, щоб мінімізувати контакти та скоротити витрати часу в умовах стаціонару.

Саме телемедицина дає змогу медичним закладам збільшувати ресурсне забезпечення вдосконаленими аудіовізуальними інтерфейсами. Одним із найкращих щодо реорганізації охорони здоров'я в умовах пандемії є приклад США, де telelealth carts, що використовували для програми телеінсульту, були передислоковані для використання у COVID-відділеннях [5].

Система охорони здоров'я США надала цікаві дані про доцільність та вплив технологій телемедицини з підтримкою відеозйомки на надання кардіологічної допомоги. Виявилося, що на початку пандемії (протягом 1-го місяця - березень 2020 р.) телевізити до лікаря при невідкладних станах зросли у 8 разів [6].

Що стосується стаціонарної допомоги, то пандемія дала зрозуміти, що tele-ICU - це майбутнє інтенсивної терапії. Досвідчений фахівець із критичної допомоги може надати підтримку пацієнту в режимі реального часу, водночас оцінюючи його реакцію на зміну режиму вентиляції легень та безпечно виконуючи віртуальні обходи за допомогою аудіовізуального (A/V)-обладнання.

Більше того, tele-ICU може бути суттєвою перевагою для Heart team під час розширеної серцево-легеневої реанімації. Оскільки в таких обставинах час має принципове значення, можливість за декілька секунд віртуально (за допомогою A/V-технологій) доставити лікаря інтенсивної терапії до палати може значно пришвидшити життєво важливі заходи. Така віртуальна присутність дозволяє зменшити кількість персоналу, який проводить реанімаційні заходи, і вирішує питання недостатньої кількості медичних працівників в умовах COVID-19 [7].

Для полегшення кардіологічної допомоги у стаціонарі в умовах перенавантаження, яке викликане пандемією, створений мобільний додаток COVID Caregiver Cockpit [8]. Цей додаток - засіб безконтактної взаємодії з пацієнтами, що включає функцію негайного сповіщення при погіршенні стану. За допомогою цього додатку лікарі мають змогу проводити швидкий огляд тих пацієнтів, які потребують невідкладної допомоги.

\section{CardioMEMS та інші технології дистанційного моніторингу}

Кардіолог з Румунії та голова з медіакомунікацій Робочої групи з телекардіології Mihai Trofenciuc у своїй доповіді закцентував увагу на нових методах моніторингу $\mathrm{CH}$, а саме - імплантованих пристроях.

$\mathrm{CH} \in$ основною причиною госпіталізації у країнах Західної $\epsilon_{\mathrm{B}}$ ропи. Серед людей віком >65 років, яким надається первинна медична допомога з приводу задишки при фізичному навантаженні, кожен 6-й має нерозпізнану та недіагностовану СН (переважно СH зі збереженою фракцією викиду лівого шлуночка) [9].

Протягом останніх десятиліть метою ефективного ведення паці$\epsilon$ нтів із СНбуло виявлення найкращого методу моніторингузастійних симптомів для запобігання госпіталізації. Оскільки N-термінальний промозковий натрійуретичний пептид (NT-proBNP) не може надійно передбачити смертність або загальний рівень госпіталізації з приводу $\mathrm{CH}$, в останні роки розроблені нові пристрої для ефективного моніторингу, такі як CardioMEMS. У реаліях COVID-19 така система віддаленого гемодинамічного моніторингу цілком заслужено посіла центральне місце серед усіх пристроїв для контролю симптомів $\mathrm{CH}$, маючи найбільшу доказову базу з ефективності.

Ще до пандемії COVID-19 прилади для дистанційного контролю, такі як імплантовані сенсорні системи контролю тиску в легеневій артерії (PAP monitoring), з'явилися як дієвий спосіб подолати довгий часовий інтервал між відвідуваннями лікарів, дистанційно спостерігати пацієнтів та забезпечувати їх безпеку, вчасно виявляючи прогресування захворювання.

Згідно з останніми рекомендаціями щодо використання приладів CardioMEMS, їх імплантація показана пацієнтам із CH (III клас за NYHA), госпіталізованих із приводу СН протягом одного року до моменту імплантації. Електронний блок такого приладу щодня передає дані про показники тиску в легеневій артерії. Ці дані можуть бути використані лікарями для зміни терапії у разі СН (переважно шляхом коригування дози діуретику) до розвитку застійних симптомів [10].

Беручи до уваги результати багатьох досліджень, можна зробити висновок, що доступні технології дистанційного моніторингу, такі як HeartLogic, CardioMEMS, Vree Health тощо, забезпечують кращу клінічну оцінку стану пацієнтів із $\mathrm{CH}$, дотримуючись принципів соціального дистанціювання завдяки віртуальним відвідуванням.

Щодо найпопулярніших мобільних та веб-додатків 2020 р. для ведення пацієнтів із СН лікарям доступні такі варіанти, як TreatHF та CardioSmart Heart Explorer. TreatHF використовують для вибору оптимального методу терапії пацієнтів із СН. Інший варіант CardioSmart Heart Explorer — пропонує новітні вдосконалені зображення органів серцево-судинної системи з високою роздільною здатністю та анімацію, що дає змогу лікарям переглядати, демонструвати зображення та обговорювати проблеми з серцем та можливі варіанти лікування з пацієнтами та колегами.

\section{Список використаної літератури/References:}

1. Fisher N.D.L., Curfman G. et al. (2016) Hypertension — A Public Health Challenge of Global Proportions. Global Burden of Disease Study Lancet 2016, 388: 1659-1724. doi:10.1001/ jama.2018.16760.

2. Beaney Th., Schutte A.E., Tomaszewski M. et al. (2018) May Measurement Month 2017: an analysis of blood pressure screening results worldwide. Lancet Glob. Health, 6(7): e736e743. doi:10.1016/S2214-109X(18)30259-6.

3. Duan Y., Xie Z., Dong F. et al. (2017) Effectiveness of home blood pressure telemonitoring: a systematic review and meta-analysis of randomised controlled studies. J. Hum. Hypertens., 31(7): 427-437. doi:10.1038/jhh.2016.99.

4. Omboni S., McManus R.J., Bosworth H.B. et al. (2020) Most Recent Comprehensive International Evidence and Recommendations on the Use of Telemedicine for the Management of Arterial Hypertension: An International Expert Position Paper. Hypertension, 76(5): 13681383. doi:10.1161/HYPERTENSIONAHA.120.15873.

5. Wosik J., Fudim M., Cameron B. et al. (2020) Telehealth transformation: COVID-19 and the rise of virtual care. J. Am. Med. Inform. Assoc., 27(6): 957-962. doi:10.1093/jamia/ocaa067.

6. Mann D.M., Chen J., Chunara R. et al. (2020) COVID-19 transforms health care through telemedicine: Evidence from the field. J. Am. Med. Inform. Assoc., 27(7): 1132-1135. doi:10.1093/ jamia/ocaa072.

7. Srinivasan S.R. (2020) TELE-ICU in the Age of COVID-19: Built for this Challenge. J. Nutr. Health Aging, 24(5): 536-537. doi:10.1007/s12603-020-1376-6.

8. Schinköthe T., Gabri M.R., Mitterer M. et al. (2020) A Web- and App-Based Connected Care Solution for COVID-19 In- and Outpatient Care: Qualitative Study and Application Development. JMIR Public Health Surveill, 6(2): e19033. doi:10.2196/19033.

9. Ponikowski P., Voors A.A., Anker S.D. et al. (2016) 2016 ESC Guidelines for the diagnosis and treatment of acute and chronic heart failure: The Task Force for the diagnosis and treatment of acute and chronic heart failure of the European Society of Cardiology (ESC) Developed with the special contribution of the Heart Failure Association (HFA) of the ESC. Eur. Heart J., 37(27): 2129-2200. doi:10.1093/eurheartj/ehw128.

10. Abraham W.T., Fiuzat M., Psotka M.A. et al. (2020) Heart Failure Collaboratory Statement on Remote Monitoring and Social Distancing in the Landscape of COVID-19.JACC Heart Fail, 8(8): 692-694. doi:10.1016/j.jchf.2020.06.006. 